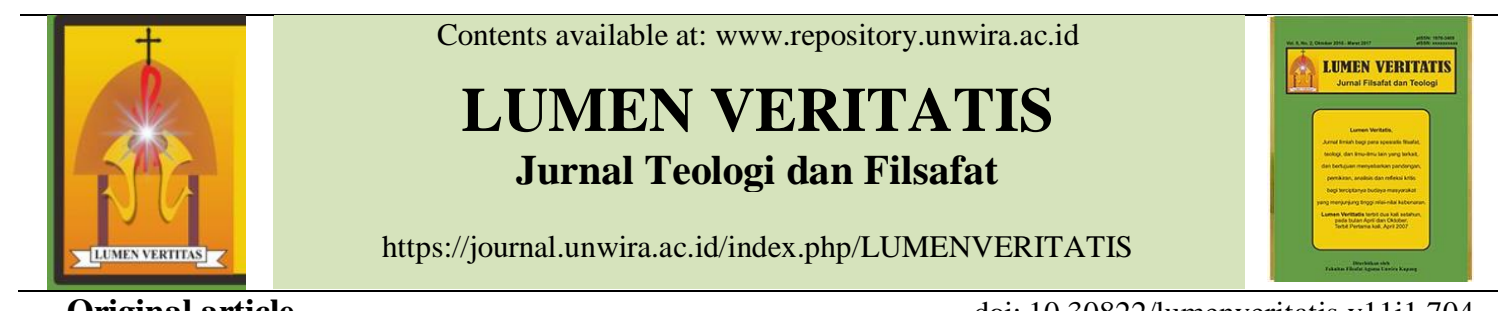

Original article

doi: 10.30822/lumenveritatis.v11i1.704

\title{
HUMAN RIGHTS AND THEIR CONTEXTUALIZATION: AFRICAN CHARTER ON HUMAN AND PEOPLE RIGHT OF 1981
}

\author{
Calestino Victor Mussomar \\ Contemporary Political Doctrine (SP/02) at the University of Rome Tor Vergata \\ Email: celestinovictor@gmail.com
}

\begin{abstract}
The aim of this article is to propose a theoretical reflection of the urgent contextualization of Human Rights in African countries. As we know, Human Rights are transversal, that every people are a consequence of historical, social and political contexts. This article tries to defend that it is possible to avoid Western imperialism in the name of Human Rights with its form of universalism. For Africa, the context of Ubuntu is a good alternative.
\end{abstract}

Keywords: Human rights, Contextualization, Humanity, Dignity, Person, Ubuntu, Demobuntocracy

\section{Introduction}

We would suggest the theory of contextual political theory/political philosophy in order to think about contextualizing human rights. Finally, we will present the African experience of contextualization of Human Rights with the African Charter on Humanand People Rights. The concept of Ubuntu is urgent if speak of democracy as as Demobuntocracy. ${ }^{1}$

\section{Towards contextual philosophical theory of human rights}

A political theory of Human Rights is necessary for the contextual approach.

${ }^{1}$ Demobuntocracy is African vision of democracy in African context of dialogue with the postcolonialinstitutions where democracy is seen as deliberative and inclusive with the participation of all according to Ubuntu's Spirit. So, demobuntocracy can become democracy since it
From an ancient age until today, the philosophical debate was concentrated on the relationship between freedom and power for common good. The critical reflection was concentrated on the function of the public institutions (Maffettone 2014, 14). Today political philosophy is living challenges which must respond to new frontiers. The paradigm which we propose is a contextual political theory, in which the reflection is concentrated in the contextual condition in relationship with the actuality, where humanity, the person and openness is at the centre.

The contextual political philosophy becomes a philosophy of actuality in the

is the African vision of Ubuntu. In fact, Ubuntu is African humanism where the person is in the first place in his relationship with the society. Demobuntocracy is the African vision of democracy with is deliberative and inclusive. 
sense that it tries to respond to the question or the problem of humanity in a determinate place and time. The actuality, in this case, is the situation of the knowledge and reflection where it is characterized with contemporaneity with the age in development. In this case, the contextual political theory becomes intercultural (Fornet-Betancourt, 2006) and trans-cultural in its reflection (Maffettone, 2014, 81). Interculturalism is the dialogical dimension between cultures. Therefore, contextual philosophy is a philosophy of dialogue when it tries to respond to the question of the complexity of our contemporaneity.

As we know, today with the global injustice, like the issues of ecology, peace, migration, involution of the State and democracy etc. it is urgent to think of a new form of political philosophy. The contextual political philosophy becomes more intercultural and more transcultural in the sense that it helps us to think about a new culture where all cultures participate actively and not passively while cooperating for the good of humanity. Thus, the concept that can characterize the theory of contextual political Philosophy as intercultural and trans-cultural has to be open to other Human beings contrary to the inclination of domination. Consequently, humanity must become a category for decision making.

The contextual approach takes the theoretical and practical vision simultaneously. It is a realistic and normative or utopian vision. In this case, a realistic approach tries to reflect the political or historical action at the moment and at the same time it does not forget the utopian aspect of a political issue. In other ways, the normative approach tries to reflect how politics must be (Petrucciani, 2003, 12-20) without forgetting the realistic vision. With the dialogical dimension, the contextual and the communicative aspect, the relationship becomes a very important existential category. Therefore, the contextual approach does not see political life as a closed system but in continuous communication between person and nature, inside and outside. In our present society, it is very important and it is possible not to share the same cause but to become part of the consequence.

The contextual approach does not only avoid the speculative reality, but it tries to concretize it. So, when we speak of the person and his dignity, we should see the concrete person with his own history and life in a determinate context. In this case, the dignity of a person is to save its life in the present moment and place. So, the category which the contextual political theory takes seriously is life as that which unites every people promotes it in different dimensions. In this case, power becomes the capacity to save life in the context of an interaction between people for the common good.

Political philosophy reflects the interaction between persons inside society in relationship and distribution of power (Petrucciani 2003, 5). To think about political interaction between people is the key to the relationship between freedom and power without which we have the conflicting dialectic mentality or an agonistic vision of politics. In the place of dialectical conflict, contextual political philosophy is integral as it tries to analyse the political life in a dialogical vision. Therefore, it is interdisciplinary and tries to see the political sphere in a holistic way.

The complexity of our actual condition needs global knowledge 
(Morin, 2015) where it is important to see the relation of different parts. The holistic epistemology gives us the possibility to reflect the complexity of the political life where the relationship between the part and the all-in politics is possible in the sense of openness. The contextualization according to Morin is like an imperative category for complex knowledge. In this case, political philosophy must be contextual. When we think in a contextual way, we are reflecting about political philosophy with the vision that political life needs to include in its analysis the poetical dimension of the living human being in a wholistic manner.

The contextual political philosophy becomes the way for recovering the poetical part of politics as love, emotion, affection and all the dimension of life. It's a necessary process for the humanization of politics where we can recover the dimension of «the politics» in the sense of the «art and science which reintegrate the human being in active harmony with the universe» (Pannikar, 1995, 47). In this way, in the political theory of Martha Nussbaum's normative approach (Nussbaum, 2013), an attempt is made to recover the poetic dimension of the human being in politics as emotions, humanism and love. Nussbaum's intuition becomes the fundamental complement for Rawls's theory of justice according to G. Vattimo (Vattimo, 2018). In fact, for Nussbaum, love and emotions are very important for the process of creation of the just and liberal society (Idem, 2018, 158-168). In the vision of contextual political Philosophy, we can say that Human Rights became more contextual, in the sense which we reflected the concept contextual, more became trans-cultural, and transversal between cultures.

Originally Human Rights are contextual because they are historical rights. According to Norberto Bobbio, Human Rights come out in a concrete historical context (N. Bobbio, 1990), (L. Ferrajoli, 2018, 15), a product of struggle for freedom against the ancient powers.

Human Rights are a transversal matter also in the sense that they are born in a contextualised place. We can get their foundation in the respect of human dignity. The spirit of Human Rights becomes in this case transversal to every culture, people and person. So, after the Universal Declaration of Human Rights, ${ }^{2}$ every people tried to contextualize them in their own way because they believed in the spirit of Human Rights even if they did not or do not accept the Westernization of shared Rights what Eric Hobsbawm calls the "imperialism of Human Rights".

Human Rights, in the Western vision, created scepticism in other contexts because in its name the West continues with the spirit of imperialism by imposing on other people a Western ideology. A double question arises: What are the hermeneutical criteria to distinguish between Human Rights and Western ideology? How must these Rights be respected in a context that is different from the Western view? The Asian, African and Latin American vision of Human Rights are connected with the concept of Humanity. This goes beyond the concept of individualism as accentuated in Western culture. The concept of Humanity is a criterion for the contextualization of Human Rights.

210 December 1948 
In the political vision of Romano Guardini, the basic concept of the political problem emerges, especially when he wonders «How does the political problem of the people and the State stand with regard to humanity? » (Guardini, 1924). This question is actually essential: let's just look at the question of immigrants to date both in Europe or North America, those inside of Africa or in Australia and Asia. Even the situation of poverty in the world is really one of abuse of Human rights. Can we continue to see the world divided: On one hand the rich people who can afford more necessities than they need, while on the other hand the poor having nothing for their basic living. Besides, the opulence, the wealthy contribute more to pollution than the poor people. From that point of view, the ecological issue becomes more and more dramatic.

We see the concept of the State as connected to territory and citizens becoming more and more questionable. The relevance of Guardiani's thought becomes essential in this context. The concept of humanity, according to Guardini, «begins to emerge in the horizon as a distinct political entity» and «the future of European States will be decisively determined by their ability to relate to this entity-(humanity) » (Guardini, 1924). So, Guardini argues that in future the State will have to give space to the person and humanity. As we can see in the Asian, African and Latin American contexts, Humanity is basically the criterion for contextualization of Human Rights. This criterion presupposes the concept of "openness". If an individual is closed, he is not able to recognise in other people or persons their human dignity.

Latin America was the first part of the world which contextualized Human Rights through the American Convention on Human Rights, adopted at the InterAmerican specialized conference on Human Rights in $1969 .{ }^{3}$ The second one was the African Charter on Human and Peoples Rights Adopted in Nairobi on June 27, 1981. The African charter rejects the imperialism and exploitation as a violation of Human Rights because when the African States proclaimed the Charter most of them had just obtained their independence. The third was the Asian's Human Rights entitled The people's charter, declared in Kwangju, In South Korea, on May 17, 1998 on the occasion of the 50th Anniversary of the Universal Declaration of Human Rights. The concept of Humanity highlighted the contextualisation of Human Rights accepted as "our common humanity" and in the preamble demonstrated the desire of the Asian people to live in Peace and Dignity.

These three forms of contextualization of Human Rights suffered from structural violation though containing good proposals. What is missing is the application of these proposals within real political frameworks. Do African Countries have the institutions for that? If not, what kind of institutions must they build?

\section{African charter on human and people rights of 1981}

In the African context, there are two lines of reasoning about Human Rights. One line considers Human Rights as an importation from the West. According to the point of view of this line; Human

\footnotetext{
${ }^{3}$ San José, Costa Rica, 22 November, 1969.
} 
rights cannot communicate with African cultures or that the heritage of African Human Rights is alien to African people. On the other hand, there is the position of those who affirm that African cultures have values which can legitimize and reinforce Human Rights. Both visions are missing the real problem of African modern countries which is the problem of corrupt leadership and the lack of strong institutions. The rule of law is equally as challenge. Africa must promote the a culture of legality and must try to create conditions that condone impunity. The abuse of Human Rights in most African countries is not a speculative situation but a real problem. In other words, African countries are trying to contextualize Human rights in an optimistic way. Today what is important is not so much as to continue with afro-pessimism analysis or Afro-optimistic analysis but with the methodological criticism with the objective to contextualise the Human Rights declared in 1948 in African countries.

The African Charter on Human and People Rights must be seen as a form of contextualization of Human Rights and what it means to create strong institutions which favour its application, respect and protection. To say Human rights are fundamental rights means that all people are equal, in the sense that these rights are recognised for all persons (Ferrajoli, 2018, 6). Universalism requires recognising the rights for all people and the idea that no one can be excluded. Fundamental rights are not private rights but rights of equality. According to Ferrajoli, we are equal in liberty rights, civil rights, political rights and social rights (Ferrajoli, 2018, 6). So we can say that « fundamental rights are the juridical basis of equality» (Ferrajoli, 2018, 6).
Fundamental rights are contrary to discrimination of the person and defend the right to life. In essence, without life, other rights do not make sense. So, we need to refuse war because it is a negation of the right to life, freedom and social rights. Therefore, we must respect and protect the dignity of the human person defending his integrity because fundamentals rights are inalienable. The reflection which arises about African abuse of Human Rights is: Why African countries signed the convention and the normative precepts which they do not obey? They have many normative instruments. All these beg the question why they do not apply these normative instruments? Since African independence, we see warfare, diseases and systemic abuse of Human Rights.

Indeed, African countries are members of the UN and advocate for the respect of Human Rights and they recognise the Universal Declaration of Human Rights. In this case, they must protect and respect them. Africa is a signatory of different convections, yet paradoxically the African situation does favour adherence. According to Stephan MacCarthy «Human Rights for Africans will not be achieved by declarations or by philosophical arguments concerning what are traditional African rights and what are Western cultural imports» (MacCarthy, 1994, 109). Human Rights in the African context will only emerge as an African solution that starts with the emergence of new rulers who will themselves see the need and be compelled to respect Human Rights.

Most African countries are constitutionally democratic but effectively they are not. Many cases of abuse of Human Rights relate to malpractices that follow national general 
elections. Then there is also the tendency of African Presidents to change constitutions after expiry of term limits so that they can serve for a Third term of even more terms in office. So, in most African countries the abuse of Human Rights is connected with the situation of unconstitutionality. Most African presidents and their governments are in situations that are at variance with their own constitutions. The example of Burundi is emblematic. Before stepping down and before his sudden death, former Pierre Nkurunziza unleashed a major constitutional crisis in 2015 when he changed the constitutional and ran for a third presidential term mandate which he dubiously won. What followed this constitutional illegality in Burundi was an unprecedented situation that created violence and the widespread abuse of Human Rights leading to many deaths. The other example is the Democratic Republic of Congo (DRC), where President Joseph Kabila remained in office for two more years despite his second term having expired in 2016. This situation in DRC created violence, demonstrations and abuse of Human Rights. The DRC has a reputation for inequality, corruption, even if it is the richest country in resources. This makes the country to be powerless and less influential on the world stage.

The odyssey does not end with these two countries. In Ivory Coast, there was violence after the election in 2012. The post-electoral crisis started when the expresident Laurent Gbagbo did not recognise the victory of Alassane Ouattara after the election in 2010. This violence led to the death of many persons in different places of the country. Another example is from Gabon where, in 2016, there was violence after President Ali Bongo
Odimba was Re-elected. His rival, Jean Ping did not accept the result affirming that the election had been fraught with irregularities. The violence led to several waves of the abuse of Human Rights.

In most of African countries, violence has become structural violence because the asymmetrical economic situation creates social conflict. Most African societies have no minimum wage as a result disease and criminality abound due to the social conditions. Capitalism in its neoliberal form is now the basic cause of violence in Africa, and the continuous political, economic and social instability. Nigeria is a tangible example of how Capitalism becomes a tool that create social and political violence (A. Traoré, 2002). The same can be said of South Africa post-apartheid with the increase xenophobic attacks all connected with the economic asymmetric situation in the society.

The economic inequalities lead to increase in a conflicting social environments. So, the economic apartheid or economic inequalities lead to the abuse of fundamental rights which have their foundation in the concept of inequality. The challenge African countries now have is to create conditions where they can reduce economic inequality for the creation of social peace. In fact, it is elusive to think that is possible to live in peace when most people in African countries are living in conditions of extreme poverty. Therefore, social peace will be the fruit of reducing material inequalities (Ferrajoli, 2018, 70).

In Africa, we see situations in which the minority population is becoming richer, while the majority of the population is becoming poorer. African States have weak control of the economy and the economic powers in the majority transnationals are controlling the African 
states in conjunction with the elites who are in governments. The economic powers are interested in weak states for control of African resources even if these African are abusing Human Rights. The lack of legality in most African countries, corrupt leaderships who insist on staying in power with vested interests so that they can continue doing their business. How can African populations change this situation? How can they make elections an opportunity for change when the elections in Africa have simply become a rite? So, the reality is that post-electoral problems persist among African states despite normative instruments, the African charter on democracy, elections and governance. The African Charter was adopted with the aim of avoiding these very post-electoral crises in Africa, just alluded to. The eighth ordinary session of the assembly of the African Union, held in Addis Ababa, Ethiopia, 30 January 2007 meant to cure these challenges. The question of Africa is therefore not the lack of norms but the lack of application. Africa needs to grow a mentality of respect for norms and the rule of law.

In this case, is not necessary to have strong leaders in Africa but stronger institutions. Which form of government would be preferable to respect and protect Human Rights in African countries' post elections? Why do African leaders insist on remaining in power even unconstitutionally? How to avoid the post-electoral conflict or crises in African countries? African leaders want to maintain power because they think that they are the owners of the State. The State is like their property, property of their family or of the political party. As the result of their struggle against colonialism, they feel entitled to all national resources as their personal reward. This wrong mentality of the monopolization of power continues to this day and can only change if individuals acknowledge and live by a culture of the common good. So, the abuse of Human Rights with the postelectoral crises is the consequence of a mentality of autocratic proprietorship over State power by African leaders. Africa needs to urgently change this mentality. State power is not the property of one person, a family. African countries must create conditions which can lead to society governed by the rule of the law. It is time for Africa to see leadership as service for one's country and for the common good. countries for a common good. This also means leading with responsibility and accountability. African leaders need to respect the public sphere. They should not try to monopolise and transform as private property what belongs to the common good. The other problem is African leaders have more immunity as a result live impunity. The lack of leadership and servant leadership styles that are imbued with the spirit of service, responsibility and accountability create the situation of continual conflict in Africa. What is needed is a selfconsciousness where effective democratic decisions can triumph over the wishes of individuals.

In the situation of most African countries living without peace and democracy, it is impossible to speak about the respect of Human Rights. Democracy and peace, according to Norberto Bobbio are interconnected issues. Since Africa's independence, most countries formally have political, civil, social rights and freedoms but concretely there is a lack of respect for Human Rights, except perhaps in countries such as Botswana and Mauritius, where the Human Rights 
today are still respected. It is not easy to speak today in Africa of the freedom of speech and liberty of association in environments where the mass media are controlled by the elite. In this case, what is the role of political parties? What kind of multiparty democracy would we expect?

Africa has witnessed horrible massacres in the last 50 years. What we see from the beginning of African independence up to now is violence in deferent forms with the abuse of Human Rights. ${ }^{4}$ After Uganda's Idi Amin Dada (1971-1979), Macías Nguema (Equatorial Guinea, 1969-79), Jean Badel Bokassa (Central African Republic, 1966-79) regimes, in 1981 the Organization of African Unity (OAU) proclaimed its own African Charter on Human and People's Rights in Nairobi to avoid the abuse of Human Rights. The African Charter was ratified by most OAU members. It entered into force on 21 October 1986. According to Stephen MacCarthy, the African Charter is «a defective document in many ways» (MacCarthy, 1994, 108) because, firstly, it asserts the rights of people rather than of individuals. The MacCarthy's criticism is clear but there is a historical context to the way to this. Many African countries at the time were leaning more towards Communist models and ideas of self-determination. The liberation Movements represented the People and

\footnotetext{
${ }^{4}$ Hutus in Burundi in 1973; Idi Amin's regime in Uganda (1971-79); Central Africa Republic during the Jean- Badel Bokassa's regime (196679); Equatorial Guinea under Macías Nguema (1969-79); Nigeria's civil war or the Biafran war 1967; The Apartheid regime in South Africa until 1994; Genocide in Rwanda 1994; Warfare in the Democratic Republic of Congo; Liberia, Burundi, Somalia, Ethiopia-Eritrea (1991); Mozambique
}

the State represented the People. So, there was no place for individuals. The second argument is that the African Charter sits firmly on the development framework but the problem is that the State dictates what is good for its subjects. Even now, many African countries call themselves democratic countries but indeed, there is no democracy because we cannot speak of democracy in situations where there is no peace. The well documented violation of Human Rights (Bobbio, 1990) negate the culture of democracy. In this case, it becomes necessary to underline first the importance of the rule of law and that of strong institutions. It is the latter reasons that also justifies the criticism of MacCarthy when he affirms that the African charter «is unique in also imposing duties on peoples, notably the duty not to compromise the security of the State and to pay taxes» (MacCarthy, 108).

We can say that the big question is not defectiveness of the African Charter but its application as the consequence of lack of institutions. In fact, the African Charter contains great proposals as in article 4, when it affirms «Human beings are inviolable. Every human being shall be entitled to respect for his life and the integrity of his person. No one may be arbitrarily deprived of this right $»$. It also recognises life, which is a fundamental right. The point is that African countries do not have the institutions which can protect and respect this right. What African

(1976-1992) and (2012-2014); Angola, Namibia, Somalia-Ethiopia (1977-78); Somalia's invasion of the Ogaden region of Ethiopia, Guinea Bissau (1998-1999); Mali, Libya (2011); Sudan (1994), until the separation of South Sudan ( 2011) in 2013 the South Sudanese civil war started; Libya (2018). 
countries should do is to build strong institutions that can avoid corruption and structural violence. A small elite continues to manipulate for its own interests. The African Charter has not been fully applied up to now (G. Finizio, 194) even if many African countries ratified it. Africa's elite minority will not allow the implementation of an instrument that diminishes their complete hold on sovereignty.

The is also the issue that the African Charter on Human and People Rights does not have punitive powers. The problem is African Union does not the equivalent of a Supreme Court that can intervene in certain juridical violation. A more superior court would go a long way in overcoming these juridical dysfunctions.

\section{Ubuntu as African human rights}

What is important now for Africa is the need to create strong institutions with the participation of the people, this process should come from African themselves. They need to take different normative documents and apply them even if this goes contrary to the interests of those who see Africa merely as a source of resources. The Application and success of the African Charter on Human and People Rights over institutions calls for a united Africa. One State alone is very weak, and is very easy to manipulate. Today it is urgent to create an African humanism, where Ubuntu is the basis and person is in the first place. In this way, it is possible to contextualise Human Rights in Africa because African humanism, Ubuntu, is a possible premise where the African Charter on Human andPeople Rights could be maintained. Ubuntu, in African culture, is incarnated in HumanRights. In most African cultures if someone has a good heart, people say he/she has Ubuntu. Ubuntu is humanity, solidarity, dignity, justice; honesty, responsibility and accountability.

In Ubuntu, Human beings are connected and the freedom of a person is understood inside his or her relation with others. Justice is restorative. Justice should not be punitive but its finality is to integrate the person within the society. For example, South Africa after Apartheid, has given the importance of Ubuntu. The end of reconciliation is to start the process of peace with restorative justice. The elites who control different countries in conjunction with transnational institutions will always resist the reduction of their power with those of the Commission of the African Charter on Human and People Rights. In fact, the Commission of the African Charter on Human and People Rights is a political institution which has no real jurisdiction cannot apply sanctions. This challenges being demonstrated here tell us that we need to contextualize Human Rights and that the African States must contribute to this process. It must be borne in mind that it will be impossible to contextualise the Human Rights without Ubuntu.

There is no other way for Africa to proceed towards Pan-Africanism without Ubuntu or Humanity. It is necessary for the success of Human Rights education to be in harmony with the spirit of Ubuntu. Today more and more it is clear for Africa that without Ubuntu there no Africa. How can Ubuntu's Spirit be proposed in an actual African society where persons are living in the Hobbesian vision? In this context, Ubuntu is a compass which can guide society which seems to have no alternative route. 
First of all, it is essential to build democracy in the African context, to make dialogue between African democracy and modern systems (N. Mandela, 1994), (A. Sen, 2010, 12-13). If African countries want a continent peaceful that respects Human Rights or if Africa wants to see the contextualization of the African Charter on Human and People Rightsit must maintain the spirit of Ubuntu and build "Demobuntocracy". Demobuntocracy is an African vision of democracy in the African context of dialoguewith postcolonial institutions. Democracy is seen as deliberative and inclusive with the participation of all according to Ubuntu's Spirit. So, demobuntocracy can become a new model for democracy since it is the African vision of Ubuntu. In fact, Ubuntu is African humanism which places the human person in the first place in his relationship with society. Literally, Ubuntu means "I am because we are" or "a person is a person because of others". The values which describe Ubuntu are humanness, discipline, morality, altruism, responsibility, self and social consciousness, duty and accountability. In Ubuntu, there isn't the dualistic problem which until now still exists in political spheres.

This dualism is the base of dialectical conflict in the political sphere where the mentality today is, we against them. In Ubuntu exists the dialogical dialectic for peace between $I$ and $W e$ (J. Ki-Zerbo, 2008) or according to Habermas's thought we can say Ubuntu is communicative dialogue contrary of strategic dialogue (J. Habermas, 1983). Ubuntu is the African vision of Human Rights. It is the respect and protection of the dignity of human being and from this case, it is possible to say that human dignity is an integral part of Ubuntu. Many African countries are living institutional dualism of: The African culture, with its own customs and cultural heritages existing side by side with modern African institutions.

Democracy in Africa must be seen as an inclusive and deliberative process. In most African countries, democracy is formality. What is concretely in practice is "partitocracy." A small oligarchy actually retains the real power. Why does the African leadership monopolize power? Why do we see dramatic situations of conflict, war and violence? Where is the spirit of Ubuntu in the empirical experience that we see in many tragic African situation of inhumanity? The inhumanity is contrary to the spirit of Ubuntu. Ubuntu is reciprocity between person to society and society to person. African countries must humanise their institutions when emphasizing liberty and equality. This can be done through education in the spirit of Ubuntu.

\section{Conclusion}

African countries need to build a culture of service in leadership by avoiding corruption. The leader must be one who governs his or her country with accountability and should promote a culture of legality that creates strong African institutions that can combat the corruption and impunity of leaders. In African countries, the mentality of monopolization of the country by African leaders must be defeated. Only in such a way can there be a reduction of structural violence and warfare in Africa. In a peaceful society, it is possible to build presumptions for democracy. It is also possible, in such an ambiente, to respect 
and protect Human Rights. The African Charter is therefore a bridge for the contextualization of Human Rights and its effectiveness. All this will only be possible if African countries create the solid affirmation of peace, democracy and the respect of Human rights through strong institutions imbued with the concept of Ubuntu.

\section{References}

CANFORA, L., esportare la libertà: il mito che ha fallito, Mondadori, Milano, 2007.

_., La natura del potere, Laterza, RomaBari, 2009.

FINIZIO, G., L'Africa sovranazionale, storia e istituzioni del regionalismo africano, Carocci Editore, Roma, 2018.

FERRAJOLI, L., Manifesto per l'uguaglianza, Laterza, RomaBari, 2018.

FORNET-BETANCOURT, R., Transformazione interculturale della filosofia, trad. di Giacomo Coccolini, Dehonianna LibriPardes edizioni, Bologna, 2006.

GUARDINI, R., Scriti Politici, vol. IV, trad. di Omar Brino, Opera omnia, Morceliana, Brescia, 2005.

HOBSBAWN, E. J., Imperialism, Rizzoli, Milano, 2007.

MAFFETTONE, S., Filosofia politica: una piccola introduzione, Luiss University Press, Roma, 2015.

MACCARTHY, S., Africa: The Challenge of transformation, I.B. Tauris \& Co Publishers, London-New York, 1994.
HABERMAS, J., Etica del discorso, trad. di Emilio Agazzi, Laterza, RomaBari, 2009.

MANDELA, N., Long walk to freedom: the autobiography of Nelson Mandela, Abacus, London, 1995. , Lungo cammino verso la libertà, autobiografia, trad. di Ester Dornetti, Adriana Bottini e Marco Papi, Feltrineli, Milano, 1995.

MORIN, E., 7lezioni sul pensiero globale, trad. di Susana Lazzari, Raffaello Cortina Editore, 2016.

PANIKKAR, R., Il «Daimôn» della politica: agonia e speranza, EDB, Bologna, 1995.

PETRUCCIANI, S., Modelli di filosofia politica, Einaudi, Torino, 2003.

POTESTÀ, G. L., et al., Storie di giustizia riparativa, il Sudafrica dall'apartheid allaRiconciliazione, il Mulino, 2017.

RAWLS, J., The law of People, with the idea of public reason Revisited, Harvard University Press, Cambridge, 1999.

THIONG'O, N. W., Scrivere per la pace: renderel'Afruca visibile al modo, trad. di Albertocristofori, La nave di Teseo, Milano, 2017.

SEN, A, La democrazia degli altri, trad. di Aldo Piccato, Oscar Mondatori, Milano, 2010.

WALZER, M., A guerra em debate, trad. di Luísa Feijó, Ediçoes Cotovia, Lisboa, 2004

VATTIMO, G., Essere e dintorni, La nave di Teseo, Milanom 2018.

ZAGREBELSKY, G., Dirriti per forza, Einaudi, Torino, 2017.

American Convention on Human Rights, adopted at the Inter-American specialized conference on Human Rights, San José, Costa Rica, 22 November 1969. 
The African Charter on Human and Peoples Rights, adopted in Nairobi June 27, 1981.

The Asian's Human Rights the People'sCharter declared in Kwangju, In South Korea, on 17 May 1998 in the On the Occasion of the 50th Anniversary of the Universal Declaration of Human Rights.

African Charter on Democracy, Elections and Governance, adopted by the eighth ordinary session of the Assembly, held in Addis Ababa, Ethiopia, 30 January 2007.

\section{Biography}

Prof. Dr. Celestino Victor Mussomar is an Assistent Professor of Contemporary Political Doctrine (SP/02) at the University of Rome Tor Vergata. Prof. Mussomar holds two Ph. Ds from the Department of History, Humanities and Society at the University of Rome Tor Vergata. His second Ph.D. in Philosophy is from the Faculty of Philosophy atthe Pontifical Atheneum of Sant'Anselm in Rome. His research areas are in the areas of Philosophy, Political Theory, Philosophy of Law, History of Political thought, Political doctrine, International Relations and Theology. His research interests include topics in: African Philosophy, Human Rights, Democracy, Contextual Political Theory and African theology. 